\title{
Invisibility, Illegibility, and Stigma: The Citizenship Experiences of Divorced Gays and Lesbians
}

\author{
Aaron Hoy \\ Ph.D. Candidate, Syracuse University \\ NYSSA 2017 \\ Rochester, NY
}




\section{Citizenship}

- Citizenship

- Civil or legal, political, and/or social rights (Marshall, 1950)

- Belonging and inclusion (Kymlicka \& Norman, 1994; Turner, 1993)

- Today, gays and lesbians are neither full citizens nor complete outcasts - "Partial" (Richardson, 1998) or "fragmented" (Engel, 2016) citizenship

- The campaign for marriage equality was motivated in large part by the assumption that gaining access to legal marriage would bring gays and lesbians closer to full citizenship 


\section{Same-Sex Marriage}

- Marriage can legitimize same-sex relationships in the eyes of family, friends, and co-workers (Green, 2013; Kimport, 2014; Ocobock, 2013)

- Leads to experiences of acceptance, inclusion, and support

- Many begin to feel "entirely a part of society" (Kimport, 2014: 59)

- Some do continue to face hostility (see Ocobock, 2013)

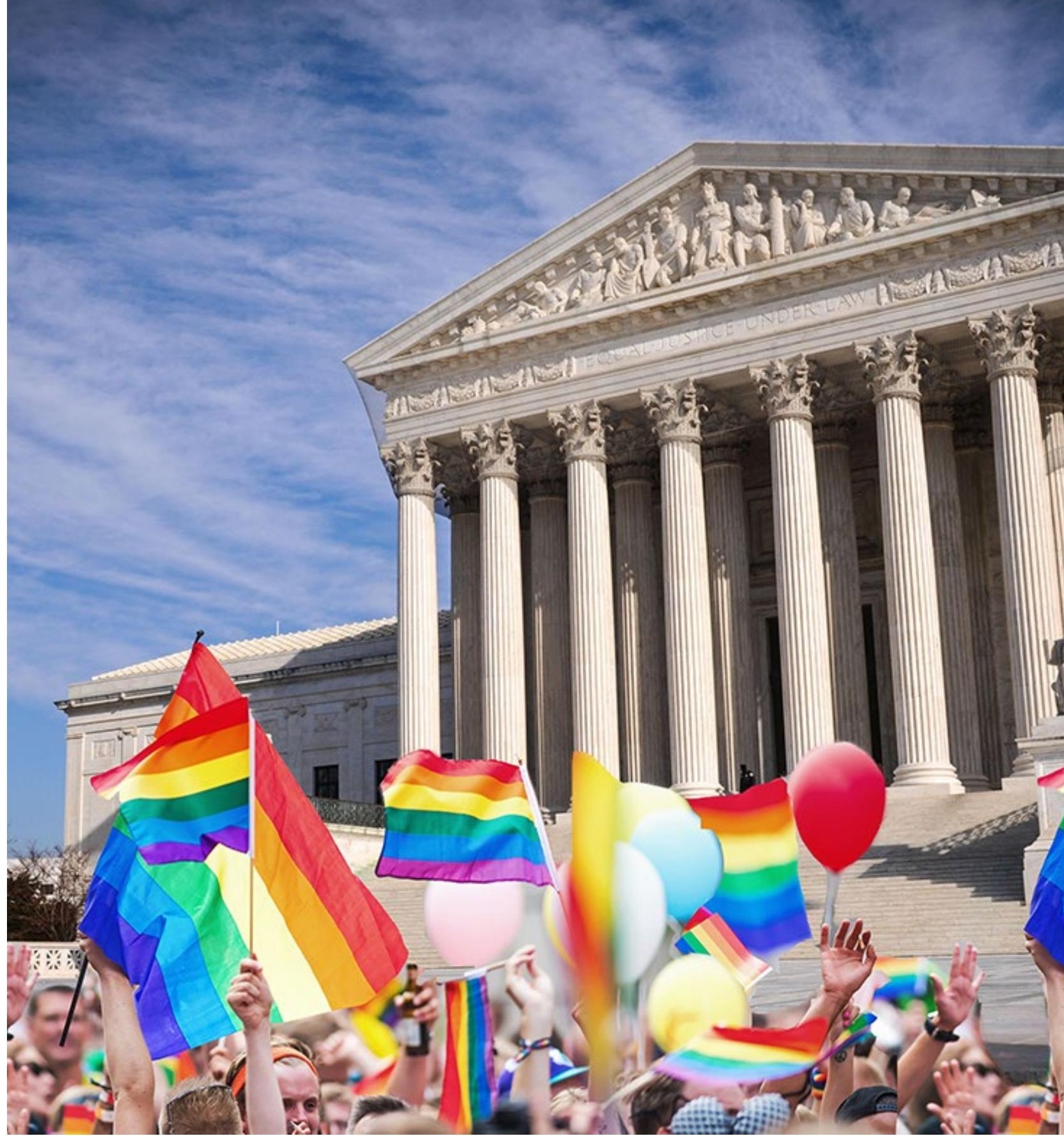




\section{Research Question}

If some of the aspects of citizenship having to do with belonging and inclusion are secured through marriage, in what ways might divorce reshape gays and lesbians'

citizenship experiences? That is, how might divorce complicate, or undo, the acceptance and support that some gays and lesbians find upon marrying?

\section{find}




\section{Methods}

- Small, convenience sample of 5

- Semi-structured, in-depth interviews

- Participants recruited through non-profit organizations and law firms, snowball sampling

- Conducted via telephone (see Goldberg \& Smith, 2008; Pfeffer, 2010)

- Lasted between 1 and 2.5 hours

- Analyzed using grounded theory (Charmaz, 2006)

- 3-step inductive process: line-by-line coding, focused coding, analytic memos 


\begin{tabular}{|c|c|c|c|c|c|}
\hline Name $(n=5)$ & Former Spouse & Children & Age & Race & Reasons for Divorce \\
\hline Jay & David & Yes & 39 & White & $\begin{array}{l}\text { Marriage was "loveless," Jay } \\
\text { was not attracted to David }\end{array}$ \\
\hline Lauren & Margaret & Yes & 45 & White & $\begin{array}{l}\text { "Different ways of existing," } \\
\text { incompatible lifestyles }\end{array}$ \\
\hline Maura & Amy & No & 46 & White & $\begin{array}{l}\text { Grew apart, lack of mutual } \\
\text { support }\end{array}$ \\
\hline Rodney & Craig & No & 54 & $\begin{array}{l}\text { African } \\
\text { American }\end{array}$ & $\begin{array}{l}\text { Infidelity, lack of trust and } \\
\text { intimacy }\end{array}$ \\
\hline
\end{tabular}




\section{Invisibility}

I feel nobody talks about the divorce. Like, hello? Everybody talks about the equality. It's like, hello, let's talk about it! If there's marriage, there's going to be divorce. So I was like, Rosie O'Donnell, she got a divorce; nobody talked about it. Ellen DeGeneres, she got a divorce; nobody talked about when Ellen broke up. These are stars. These are famous people, and they only talked about their relationships, but not when they broke up. And there's other famous people I can't think of. They just talked about marriage, marriage, marriage, marriage. No, we need to talk about divorce also because it's a serious thing. It's like, it's not a game.

- Jay (39, White, CA) 


\section{Invisibility}

You know, it's like everybody was so excited about the ability to get married, nobody stopped to think about the fact that a lot of us would divorce, too. And I think it was kind of pompous of them to think that we would have different divorce rates than our heterosexual neighbors. Like, why would it surprise us when we get divorced? If we can get married, we'll get divorced, too.

- Maura (46, White, MA) 


\section{Illegibility}

I have found that what's really funny is meeting someone. I'm just recently trying to put myself back out there, and you meet someone, and you say, 'I'm divorced,' or somehow it'll come up in a conversation. And they'll say, 'Oh, were you married...to a woman?' And I'll say, 'No, I was married to my ex, a man!' And they're like, 'Oh, really? How's that work?' What do you mean how does that work?! I got married to a man! I think it's just that people are still trying to process the fact that same-sex couples are getting married now, and some of us are getting divorced, too.

- Rodney (54, African American, FL) 


\section{Illegibility \& Isolation}

Being kind of closed off about my personal situation has prohibited me from being as close to them as I otherwise could be, with the parents in that group, who I really like. I think they're really awesome people. But I'm sort of coaching on the sidelines and chatting with the kids... [divorce] definitely puts you in a position of, if you don't want to explain your life, which is really different from everybody else's, you just don't talk about it. So in a way, it's like being back in the closet. I mean, I think getting divorced is a big closeting force because you don't want to talk about it, you don't want to explain it to all of these people... because half of them won't get it anyway.

- Lauren (45, White, MA) 


\section{Stigma}

So I think about me and Mike. Like, am I a divorcee? Is that what I am? Yes, I'm a divorcee. Is that something that he'd want to marry? I don't know. I worry. I mean, I know some of my guy friends, they would never marry a divorcee.

- Jay $(39$, White, CA) 


\section{Limitations \& Conclusions}

- A very small, relatively homogenous convenience sample

- Marriage equality thus far insufficient to create recognition for same-sex relationship dissolution

- Contrary to some arguments made on behalf of marriage equality (see Allen, 2007; Andersen, 2009; Morton, 1998)

- For gays and lesbians, some of the benefits of citizenship may be contingent on martial status

- Having the legal right to marry does not in itself lead to acceptance, inclusion, and support

- Contrary to some arguments made on behalf of marriage equality (see Goldberg \& Kuvalanka, 2012; Hull, 2006; Lannutti, 2005) 